\title{
Picky, hungry eaters in the cold: persistent substrate selectivity among polar pelagic microbial communities
}

\author{
Andrew D. Steen ${ }^{1,2} *$ and Carol Arnosti ${ }^{1}$ \\ ${ }^{1}$ Department of Marine Sciences, University of North Carolina at Chapel Hill, Chapel Hill, NC, USA \\ ${ }^{2}$ Department of Earth and Planetary Sciences, University of Tennessee, Knoxville, TN, USA
}

\section{Edited by:}

Hongyue Dang, Xiamen University, China

\section{Reviewed by:}

Jason B. Sylvan, University of

Southern California, USA

Prasanna Kumar, Annamalai

University, India

*Correspondence:

Andrew D. Steen, Department of Earth and Planetary Sciences,

University of Tennessee,

1412 Circle Drive, Knoxville,

TN 37996, USA

e-mail: asteen1@utk.edu
Polar pelagic microbial communities access a narrower range of polysaccharide substrates than communities at lower latitudes. For example, the glucose-containing polysaccharide pullulan is typically not hydrolyzed in fjord waters of Svalbard, even though pullulan is rapidly hydrolyzed in sediments from Svalbard fjords, other polysaccharides are hydrolyzed rapidly in Svalbard waters, and pullulan is hydrolyzed rapidly in temperate waters. The purpose of this study was to investigate potential factors preventing hydrolysis of pullulan in Svalbard fjord waters. To this end, in two separate years, water from Isfjorden, Svalbard, was amended with different carbon sources and/or additional nutrients in order to determine whether increasing the concentration of these potentially-limiting factors would lead to measurable enzymatic activity. Addition of nitrate, phosphate, glucose, or amino acids did not yield detectable pullulan hydrolysis. The only treatment that led to detectable pullulan hydrolysis was extended incubation after the addition of maltotriose (a subunit of pullulan, and potential inducer of pullulanase). In these fjords, the ability to enzymatically access pullulan is likely confined to numerically minor members of the pelagic microbial community. These results are consistent with the hypothesis that pelagic microbial communities at high latitudes exhibit streamlined functionality, focused on a narrower range of substrates, than their temperate counterparts.

Keywords: microbial loop, heterotrophic bacteria, Arctic Ocean, extracellular enzymes, latitudinal gradient

\section{INTRODUCTION}

Surface ocean microbial communities differ systematically in their abilities to enzymatically hydrolyze high molecular weight organic matter, and thus to initiate remineralization of high molecular weight substrates (Arnosti et al., 2011). Pelagic microbial communities at high latitude are capable of hydrolyzing a narrower spectrum of soluble substrates than their temperate counterparts, although the underlying reasons for this substrate selectivity are unknown. This narrowing of microbial community function at high latitude parallels decreases in microbial diversity and/or species richness at high latitude (Baldwin etal., 2005; Pommier etal., 2007; Fuhrman etal., 2008; Wietz et al., 2010). Nevertheless, Arctic pelagic heterotrophic microbial communities are active players in the marine carbon cycle, transforming, and respiring a wide range of substrates, despite permanently cold temperatures (Wheeler etal., 1996; Kirchman et al., 2009a). Substrate consumption in Arctic microbial communities is affected by a wide range of factors, including season, location, and nutrient levels (Kirchman etal., 2009b; Nikrad et al., 2012). The functional difference in enzyme activities observed over latitudinal gradients, and the narrow spectrum of substrates hydrolyzed by Arctic microbial communities, may thus be driven by a lack of a nutrient or co-factor required to induce production of specific enzymes by organisms possessing them, or conversely by a lack of organisms with the genes to synthesize the enzymes required to hydrolyze specific substrates.
The supply of labile DOM has been suggested to play a key role in controlling bacterial growth at high latitude (e.g., Kirchman et al., 2009b). Substrate availability in ocean waters is also highly variable: transient events, such as phytoplankton blooms or physical mixing can rapidly change the set of organic substrates present, requiring changes in expression of genes related to organic matter metabolism (Teeling et al., 2012). Here, we investigated whether an expansion in enzymatic capabilities of pelagic microbial communities in waters of the Svalbard archipelago could be achieved through addition of a factor potentially lacking in the water column: mineral nutrients (nitrate and/or phosphate), labile organic carbon or nitrogen, or a specific inducer that might be expected to activate enzyme production. As a test case, we focused on trying to enhance the activity of enzymes that hydrolyze pullulan, a soluble, glucose-containing polysaccharide. Pullulan $[\alpha(1,6)$-linked maltotriose; maltotriose is $\alpha(1,4)$-linked glucose], was selected as a test case because in repeated investigations over the past decade, we have not detected pullulanase activity in the water column of the fjords of Svalbard, although it is readily hydrolyzed at a number of sites in temperate waters. Its basic constituent, glucose, is also is found in laminarin, a substrate readily hydrolyzed in Svalbard waters (Arnosti et al., 2005, 2011; Arnosti, 2008; Teske et al., 2011). The lack of hydrolysis of pullulan in the water column at Svalbard is particularly intriguing because pullulanase activity in underlying sediments is high (Arnosti, 2008; Teske et al., 2011), and bacterial isolates have been obtained from Svalbard sea-ice using pullulan as a growth substrate (Groudieva et al., 2004). 


\section{MATERIALS AND METHODS SEAWATER COLLECTION}

Surface seawater for the pullulanase induction experiments was obtained from Isfjord, Svalb ard $\left(78^{\circ} 16.55^{\prime} N, 15^{\circ} 10.1^{\prime} \mathrm{E}\right)$ on 29 June 2005, and on 3 August 2006. Samples were kept on ice in the dark during transit (ca. $48 \mathrm{~h}$ ) to the shore-based lab in $\mathrm{Ny}$ Allesund, Svalbard. In order to assess hydrolysis rates of a broad range of polysaccharides, surface, and bottom seawater was also collected from Station J, Smeerenburgfjord $\left(79^{\circ} 42.8^{\prime} \mathrm{N}, 011^{\circ}\right.$ $05.2^{\prime} \mathrm{E}$ ) in 2006 and transported back to Ny Ålesund. Previous work in Svalbard indicates that pelagic extracellular enzyme activities are stable over a timescale of several days (Steen and Arnosti, 2011).

\section{PULLULANASE INDUCTION EXPERIMENTS}

In order to investigate whether addition of carbon or nutrient compounds potentially influenced pullulanase expression, samples were "pre-incubated" with different carbon and/or nutrient compounds prior to addition of fluorescently labeled (fl)-pullulan. In 2005, pre-incubation periods were $24 \mathrm{~h}$ and 5 days. In 2006, due to logistical constraints, pre-incubation periods were shortened to $12 \mathrm{~h}$ and 3 days. After the pre-incubation period, fl-pullulan or flxylan was added to each treatment, and polysaccharide hydrolysis rates were measured as described below. The experimental design in each year is summarized in Table 1.

In 2005, experimental treatments consisted of additions of glucose (potentially a labile source of organic carbon; $0.875 \mu \mathrm{M}-\mathrm{C}$ ), maltotriose (a trimer of glucose and a constituent of pullulan; $0.875 \mu \mathrm{M}-\mathrm{C}$ ), nitrate (potentially a limiting nutrient; $40 \mu \mathrm{M}$ ), phosphate (potentially a limiting nutrient; $16 \mu \mathrm{M}$ ), and nitrate plus phosphate (potentially limiting nutrients; 40 and $16 \mu \mathrm{M}$, respectively). Maltotriose and glucose were selected because they have been observed to induce and repress pullulanase activity, respectively (Hope and Dean, 1974; Antranikian, 1990; Nair et al., 2007). Nutrient amendments were included because low nutrient conditions can lead to low pullulanase activity even in the presence of pullulanase inducers (Nair et al., 2007). Additionally, a treatment with no addition was included as a control, and a treatment with no addition, but in which hydrolysis of fl-xylan rather than fl-pullulan was measured, was included as a positive control for microbial hydrolysis of polysaccharides.
Xylan was chosen as the positive control since previous work on Svalbard had repeatedly demonstrated rapid hydrolysis of this polysaccharide (e.g., Arnosti et al., 2011). In 2006, experimental treatments consisted of additions of glucose $(0.875 \mu \mathrm{M}-\mathrm{C})$, maltotriose (0.875 $\mu \mathrm{M}-\mathrm{C})$, unlabeled pullulan $(0.875 \mu \mathrm{M}-\mathrm{C})$, an equimolar mix of the 20 genetically-encoded amino acids (as sources of labile carbon and nitrogen; total concentration $5.25 \mu \mathrm{M}-\mathrm{C}$ ) and nitrate plus phosphate (40 and $16 \mu \mathrm{M}$, respectively). These nutrient concentrations were likely high compared to in situ nutrient concentrations, which were previously been observed in the range of $0-10 \mu \mathrm{M} \mathrm{NH}_{4}^{+}+\mathrm{NO}_{3}^{-}$and $0.1-0.7 \mu \mathrm{M}$ $\mathrm{PO}_{4}^{3-}$ in Svalbard waters (Owrid et al., 2000; Iversen and Seuthe, 2011).

\section{PROTOCOL FOR MEASURING POLYSACCHARIDE HYDROLYSIS RATES}

Fl-polysaccharides (pullulan, xylan, arabinogalactan, chondroitin sulfate, fucoidan, and laminarin,) were synthesized as described by Arnosti (Arnosti, 1996, 2003). For each hydrolysis rate measurement, polysaccharides were added to a $50 \mathrm{ml}$ sample, which was divided into three biological replicates. Samples were then incubated at $7{ }^{\circ} \mathrm{C}(2005)$ or $4{ }^{\circ} \mathrm{C}$ (2006). Subsamples were taken after 3, 8, and 21 days (2005 Isfjorden samples); 3, 7, and 14 days (2006 Isfjorden samples) or 2, 4, 6, 10, and 16 days of incubation (2006 Smeerenburgfjorden samples). Fl-polysaccharide size distributions and hydrolysis rates were calculated as described previously (Arnosti, 1996, 2003).

\section{HYDROLYSIS OF A BROAD RANGE OF POLYSACCHARIDES IN SMEERENBURGFJORDEN}

In 2006, hydrolysis rates of arabinogalactan, chondroitin sulfate, fucoidan, laminarin, pullulan, and xylan were assessed in surface (1 m depth) and bottom (ca. $200 \mathrm{~m}$ depth) at station, J, Smeerenburgfjorden. Polysaccharide hydrolysis rates were measured with no pre-incubation period, and without amendments of substrates other than the fl-polysaccharides, as described above.

\section{RESULTS}

Heterotrophs capable of hydrolyzing polysaccharides were active in the pullulan induction experiments, as shown by maximum xylan hydrolysis rates (measured in a single replicate after 21 days incubation) of $4.3 \mathrm{nM} \mathrm{L}^{-1} \mathrm{~h}^{-1}$ in the $24 \mathrm{~h}$ pre-incubation

Table 1 | Hydrolysis rates for xylan and pullulan under different experimental treatments, $\mathrm{nmol} \mathrm{L}^{-1} \mathrm{~h}^{-1}$.

\begin{tabular}{|c|c|c|c|c|c|c|c|c|}
\hline \multirow[t]{2}{*}{2005} & & No amendment & No amendment & +glucose & + maltotriose & $+\mathrm{NO}_{3}^{-}$ & $+\mathrm{PO}_{4}^{3-}$ & $+\mathrm{NO}_{3}^{-}+\mathrm{PO}_{4}^{3-}$ \\
\hline & 5 days & 6.8 & 0 & 0 & $0.86 \pm 0.13$ & 0 & 0 & 0 \\
\hline 2006 & & & No amendment & +glucose & + maltotriose & +pullulan & $+\mathrm{AA}$ & $+\mathrm{NO}_{3}^{-}+\mathrm{PO}_{4}^{3-}$ \\
\hline
\end{tabular}

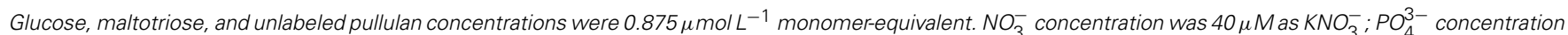

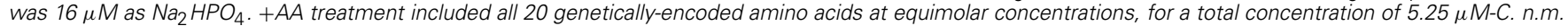
indicates that xylan hydrolysis in 2006 was not measured in Isfjorden waters. 
no-addition samples and $6.8 \mathrm{nM} \mathrm{L}^{-1} \mathrm{~h}^{-1}$ in the 5-day preincubation no-addition samples (Table 1). Moreover, four distinct polysaccharide substrates were hydrolyzed in surface and bottom waters from Station J in Smeerenburgfjord (Figure 1), consistent with previous results that pelagic microbial communities in Svalbard are readily capable of accessing specific polysaccharides (Arnosti, 2008; Teske et al., 2011).

Efforts to stimulate use of pullulan as a substrate, however, showed that pullulan is microbially-inaccessible for most of the pelagic community (Table 1). Only a single set of treatments - the 5 days pre-incubation with maltotriose-led to hydrolysis of fl-pullulan during the subsequent incubation. Even in this case, substantial incubation time (21 days) was required before detectable hydrolysis of pullulan occurred. Addition of glucose, pullulan, nitrate, phosphate, nitrate, and phosphate, and free amino acids did not lead to measurable pullulanase activity, nor did addition of maltotriose on timescales shorter than the 5 days pre-incubation +21 days incubation (Table 1 ).

\section{DISCUSSION}

The observation that addition of maltotriose led to measurable pullulanase activity after sufficient pre-incubation is consistent with biochemical control of pullulanase expression, since pullulan is composed of repeating units of maltotriose. Many extracellular polysaccharide hydrolases are regulated by a scheme in which the hydrolase is expressed constitutively at a low level (Béguin and Aubert, 1994). Oligomers of the polysaccharide induce further expression of the hydrolase, while monomers of the polysaccharide (glucose, in this example) repress expression of the homologous hydrolase. This regulation mechanism has been demonstrated for thermophilic bacteria that hydrolyze pullulan (Antranikian, 1990); the current data suggest that pullulanase activity in Svalbard waters may be regulated in a similar manner. The fact that hydrolysis was only detected after 21 days in the +maltotriose, 5 -days pre-incubation

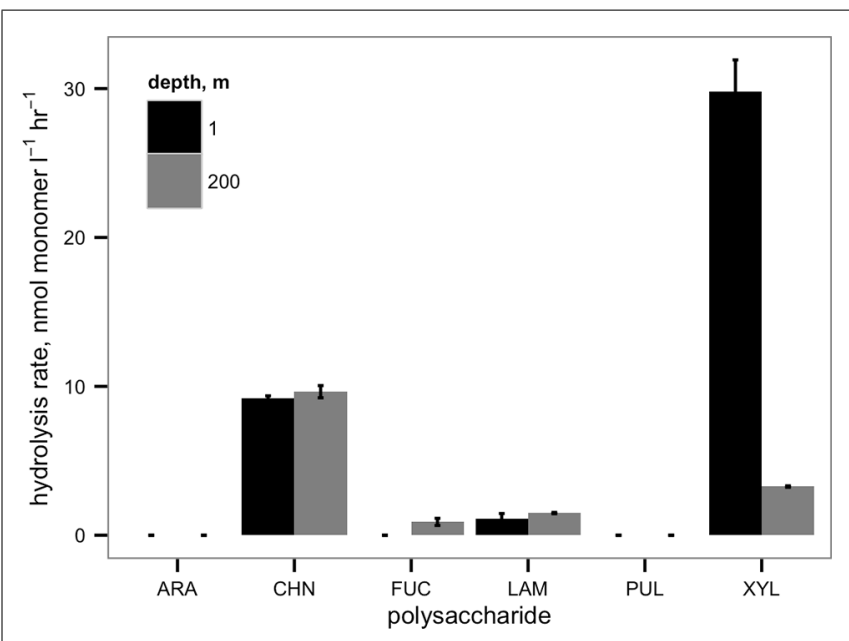

FIGURE 1 | Hydrolysis rates of six polysaccharides in surface and bottom waters at Station J, Smeerenburgfjord, August 2006. Bars represent SD. of triplicate incubations. Ara, arabinogalactan; chn, chondroitin sulfate; fuc, fucoidan; lam, laminarin; pul, pullulan; xyl, xylan. treatment from 2005 (and was not detectable with shorter preincubation periods with either maltotriose or pullulan) further suggests that the microorganisms in fjord waters capable of hydrolyzing pullulan were likely slow-growing as well as initially rare.

Induction of enzymatic pathways can occur on timescales of hours or faster in the lab (Madigan et al., 2000); and less than 2 days for hydrolysis patterns consistent with pullulanase induction in seawater at lower latitudes (Steen et al., 2012). Substrates for which the corresponding extracellular enzyme must be induced may therefore be hydrolyzed quite rapidly, if the final activity of the induced enzyme is high. The combined requirements of growth of a relatively rare member of the microbial community and induction of enzymes, however, could lead to the pattern observed in this study. Slow growth of bacteria in Svalbard waters is consistent with the results of Vadstein (2011), who found no increase in cell numbers over $22 \mathrm{~h}$ bioassay experiments in which carbon and nutrients were added to Svalbard fjord water. It is also consistent with results of very long-term incubations of surface water from Station J, in which hydrolysis of Isochrysis extract was first observed only after 70 days' incubation, activity also attributable to initially rare and slow-growing bacteria (Arnosti, 2008).

In many respects, the general absence of pullulanase activity in Svalbard waters is quite surprising, given that it is a soluble, linear polysaccharide composed of glucose. Furthermore, pullulanase functions as a debranching enzyme of starch (Ball and Morell, 2003), a common algal energy storage polysaccharide (Painter, 1983). Hydrolysis of pullulan in Svalbard sediments is rapid (Arnosti, 2008; Teske et al., 2011), and a diverse range of bacterial isolated from sea ice in Svalbard's fjords can hydrolyze pullulan (Groudieva et al., 2004). In addition, Aureobasidium pullulans, a fungus which produces pullulan, has been isolated from Svalbard fjord water (Zalar et al., 2008), so there is very likely a source of pullulan to the water we studied. Furthermore, pelagic communities in Svalbard's fjords can hydrolyze a number of other polysaccharide substrates, as demonstrated by the incubations carried out with water from Station J (Figure 1). The observation that pullulan and arabinogalactan were not hydrolyzed over the time course of incubation in the waters of Station J, however, demonstrates that specific soluble, carbohydrate-containing substrates are unavailable to pelagic microbial communities in these polar waters. The observation that these same substrates were also not hydrolyzed in incubations carried out in other years in this same fjord (Arnosti etal., 2011; Teske etal., 2011) demonstrates that the inability to hydrolyze specific substrates is a consistent feature of these communities.

Polar microbial communities are composed of different species than those at lower latitudes (Bano et al., 2004), and exhibit enzymatic activity patterns distinct from their temperate counterparts (Arnosti etal., 2011). In order to cope with the rhythms of primary productivity and plankton succession that are unique to high-latitude environments (Hop et al., 2002), Arctic microbial communities may specialize in terms of substrate sets or controlling mechanisms for key carbon cycling processes. The observation that some soluble substrates readily 
hydrolyzed in lower latitude environments are only microbially available under a very specific set of circumstances supports the view that most members of Arctic pelagic microbial communities focus on a more limited range of substrates than their temperate counterparts. These substrates are hydrolyzed at considerable rates (Figure 1; Arnosti et al., 2011), perhaps at the expense of the ability to access a wider range of substrates, including a fraction of freshly-produced phytoplanktonderived organic matter in Svalbard waters (Thingstad et al., 2008). This streamlining of metabolic function may help explain how polar communities are able to rapidly mineralize specific organic substrates (e.g., Rich etal., 1997), even at low temperatures.

\section{ACKNOWLEDGMENTS}

We thank the Max Planck Institute for Marine Microbiology for partial funding of the fieldwork, the staff of the Max Planck Institute and Elin Austerheim of King's Bay for logistical support in Ny Ålesund, Stig Hennigsen, captain of the Farm, for his dedication to the cause of obtaining samples, and Oliver Jeffers, for providing Andrew D. Steen with an unusually artistic periodic table of the elements. We appreciate the comments of two reviewers on earlier versions of this manuscript. Andrew D. Steen received funding from the U.S. Environmental Protection Agency (EPA) under the Science to Achieve Results (STAR) Graduate Fellowship Program and the National Science Foundation (OCE-1357242). The EPA has not officially endorsed this publication, and the views expressed herein might not reflect the views of the EPA. Carol Arnosti received funding from the National Science Foundation (OCE- and -1332881), as well as support from the Hanse-Wissenschaftskolleg, Delmenhorst, Germany.

\section{REFERENCES}

Antranikian, G. (1990). Physiology and enzymology of thermophilic anaerobic bacteria degrading starch. FEMS Microbiol. Lett. 75, 201-218. doi: 10.1111/j.15746968.1990.tb04095.x

Arnosti, C. (1996). A new method for measuring polysaccharide hydrolysis rates in marine environments. Org. Geochem. 25, 105-115. doi: 10.1016/S01466380(96)00112-X

Arnosti, C. (2003). Fluorescent derivatization of polysaccharides and carbohydratecontaining biopolymers for measurement of enzyme activities in complex media. J. Chromatogr. B Analyt. Technol. Biomed. Life Sci. 793, 181-191. doi: 10.1016/S1570-0232(03)00375-1

Arnosti, C. (2008). Functional differences between Arctic seawater and sedimentary microbial communities: contrasts in microbial hydrolysis of complex substrates. FEMS Microbiol. Ecol. 66, 343-351. doi: 10.1111/j.1574-6941.2008. 00587.x

Arnosti, C., Durkin, S., and Jeffrey, W. H. (2005). Patterns of extracellular enzymatic activities among pelagic microbial communities: implications for cycling of dissolved organic carbon. Aquat. Microb. Ecol. 38, 135-145. doi: 10.3354/ame038135

Arnosti, C., Steen, A. D., Ziervogel, K., Ghobrial, S., and Jeffrey, W. H. (2011). Latitudinal gradients in degradation of marine dissolved organic carbon. PLoS ONE 6:e28900. doi: 10.1371/journal.pone.0028900

Baldwin, A. J., Moss, J. A., Pakulski, J. D., Catala, P., Joux, F., and Jeffrey, W. H. (2005). Microbial diversity in a Pacific Ocean transect from the Arctic to Antarctic circles. Aquat. Microb. Ecol. 41, 91-102. doi: 10.3354/ame 041091

Ball, S. G., and Morell, M. K. (2003). From bacterial glycogen to starch: understanding the biogenesis of the plant starch granule. Annu. Rev. Plant Biol. 54, 207-233. doi: 10.1146/annurev.arplant.54.031902.134927
Bano, N., Ruffin, S., Ransom, B., and Hollibaugh, J. T. (2004). Phylogenetic composition of Arctic Ocean archaeal assemblages and comparison with Antartic assemblages. Appl. Environ. Microbiol. 70, 781-789. doi: 10.1128/AEM.70.2.781789.2004

Béguin, P., and Aubert, J.-P. (1994). The biological degradation of cellulose. FEMS Microbiol. Rev. 13, 25-58. doi: 10.1111/j.1574-6976.1994.tb00033.x

Fuhrman, J. A., Steele, J. A., Hewson, I., Schwalbach, M. S., Brown, M. V., Green, J. L., et al. (2008). A latitudinal diversity gradient in planktonic marine bacteria. Proc. Natl. Acad. Sci. U.S.A. 105, 7774-7778. doi: 10.1073/pnas. 0803070105

Groudieva, T., Kambourova, M., Yusef, H., Royter, M., Grote, R., Trinks, H., et al. (2004). Diversity and cold-active hydrolytic enzymes of culturable bacteria associated with Arctic sea ice, Spitzbergen. Extremophiles 8, 475-488. doi: 10.1007/s00792-004-0409-0

Hop, H., Pearson, T., Hegseth, E. N., Kovacs, K. M., Wiencke, C., Kwasniewski, S., et al. (2002). The marine ecosystem of Kongsfjorden, Svalbard. Polar Res. 21, 167-208. doi: 10.1111/j.1751-8369.2002.tb00073.x

Hope, G. C., and Dean, A. C. R. (1974). Pullulanase synthesis in Klebsiella (Aerobacter) aerogenes strains growing in continuous culture. Biochem. J. 144, 403-411.

Iversen, K. R., and Seuthe, L. (2011). Seasonal microbial processes in a highlatitude fjord (Kongsfjorden, Svalbard): I. Heterotrophic bacteria, picoplankton and nanoflagellates. Polar Biol. 34, 731-749. doi: 10.1007/s00300-0100929-2

Kirchman, D. L., Hill, V., Cottrell, M. T., Gradinger, R., Malmstrom, R. R., and Parker, A. (2009a). Standing stocks, production, and respiration of phytoplankton and heterotrophic bacteria in the western Arctic Ocean. Deep Sea Res. Part II Top. Stud. Oceanogr. 56, 1237-1248. doi: 10.1016/j.dsr2.2008. 10.018

Kirchman, D. L., Moran, X. A., and Ducklow, H. (2009b). Microbial growth in the polar oceans - role of temperature and potential impact of climate change. Nat. Rev. Microbiol. 7, 451-459. doi: 10.1038/nrmicro2115

Madigan, M. T., Martinko, J. M., and Parker, J. (2000). Brock Biology of Microorganisms. Upper Saddle River, NJ: Prentice Hall.

Nair, S. U., Singhal, R. S., and Kamat, M. Y. (2007). Induction of pullulanase production in Bacillus cereus FDTA-13. Bioresour. Technol. 98, 856-859. doi: 10.1016/j.biortech.2006.03.010

Nikrad, M. P., Cottrell, M. T., and Kirchman, D. L. (2012). Abundance and singlecell activity of heterotrophic bacterial groups in the western Arctic Ocean in summer and winter. Appl. Environ. Microbiol. 78, 2402-2409. doi: 10.1128/AEM. 07130-11

Owrid, G., Socal, G., Civitarese, G., Luchetta, A., Wiktor, J., Nöthig, E. M., et al. (2000). Spatial variability of phytoplankton, nutrients and new production estimates in the waters around Svalbard. Polar Res. 19, 155-171. doi: 10.1111/j.1751-8369.2000.tb00340.x

Painter, T. J. (1983). “Algal Polysaccharides," in The Polysaccharides, ed. G. O. Aspinall (New York: Academic Press), 195-285.

Pommier, T., Canbäck, B., Riemann, L., Boström, K. H., Simu, K., Lundberg, P., et al. (2007). Global patterns of diversity and community structure in marine bacterioplankton. Mol. Ecol. 16, 867-880. doi: 10.1111/j.1365-294X.2006. 03189.x

Rich, J. H., Gosselin, M., Sherr, E. B., Sherr, B. F., and Kirchman, D. L. (1997). High bacterial production, uptake and concentrations of dissolved organic matter in the Central Arctic Ocean. Deep Sea Res. 44, 1645-1663. doi: 10.1016/S09670645(97)00058-1

Steen, A. D., and Arnosti, C. (2011). Long lifetimes of $\beta$-glucosidase, leucine aminopeptidase and phosphatase in Arctic seawater. Mar. Chem. 123, 127-132. doi: 10.1016/j.marchem.2010.10.006

Steen, A. D., Ziervogel, K., Ghobrial, S., and Arnosti, C. (2012). Functional variation among polysaccharide-hydrolyzing microbial communities in the Gulf of Mexico. Mar. Chem. 138-139, 13-20. doi: 10.1016/j.marchem.2012. 06.001

Teeling, H., Fuchs, B. M., Becher, D., Klockow, C., Gardebrecht, A., Bennke, C. M., et al. (2012). Substrate-controlled succession of marine bacterioplankton populations induced by a phytoplankton bloom. Science 336, 608-611. doi: $10.1126 /$ science. 1218344

Teske, A., Durbin, A., Ziervogel, K., Cox, C., and Arnosti, C. (2011). Microbial community composition and function in permanently cold seawater and sediments 
from an Arctic fjord of Svalbard. Appl. Environ. Microbiol. 77, 2008-2018. doi: 10.1128/AEM.01507-10

Thingstad, T. F., Bellerby, R. G. J., Bratbak, G., Børsheim, K. Y., Egge, J. K., Heldal, M. et al. (2008). Counterintuitive carbon-to-nutrient coupling in an Arctic pelagic ecosystem. Nature 455, 387-390. doi: 10.1038/nature07235

Vadstein, O. (2011). Large variation in growth-limiting factors for marine heterotrophic bacteria in the Arctic waters of Spitsbergen $\left(78^{\circ} \mathrm{N}\right)$. Aquat. Microb. Ecol. 63, 289-297. doi: 10.3354/ame01503

Wheeler, P. A., Gosselin, M., Sherr, E., Thibault, D., Kirchman, D. L., Benner, R., et al. (1996). Active cycling of organic carbon in the central Arctic Ocean. Nature 380, 697-699. doi: 10.1038/380697a0

Wietz, M., Gram, L., Jorgensen, B., and Schramm, A. (2010). Latitudinal patterns in the abundance of major marine bacterioplankton groups. Aquat. Microb. Ecol. 61, 179-189. doi: 10.3354/ame01443

Zalar, P., Gostinèar, C., De Hoog, G. S., Uršiè, V., Sudhadham, M., and GundeCimerman, N. (2008). Redefinition of Aureobasidium pullulans and its varieties. Stud. Mycol. 61, 21-38. doi: 10.3114/sim.2008.61.02
Conflict of Interest Statement: The authors declare that the research was conducted in the absence of any commercial or financial relationships that could be construed as a potential conflict of interest.

Received: 20 January 2014; accepted: 22 September 2014; published online: 08 October 2014.

Citation: Steen AD and Arnosti C (2014) Picky, hungry eaters in the cold: persistent substrate selectivity among polar pelagic microbial communities. Front. Microbiol. 5:527. doi: 10.3389/fmicb.2014.00527

This article was submitted to Aquatic Microbiology, a section of the journal Frontiers in Microbiology.

Copyright (c) 2014 Steen and Arnosti. This is an open-access article distributed under the terms of the Creative Commons Attribution License (CC BY). The use, distribution or reproduction in other forums is permitted, provided the original author(s) or licensor are credited and that the original publication in this journal is cited, in accordance with accepted academic practice. No use, distribution or reproduction is permitted which does not comply with these terms. 